\title{
Tożsamość w odsłonie muzułmańskiej
}

\author{
Recenzja książki: Monika Ryszewska, Polskie muzułmanki. W poszukiwaniu \\ tożsamości, Wydawnictwo Naukowe Uniwersytetu Mikołaja Kopernika, Toruń \\ 2018, 328 stron
}

Joanna Krotofil (D) https://orcid.org/0000-0003-2308-5329

Instytut Religioznawstwa

Uniwersytet Jagielloński

e-mail: joanna.krotofil@uj.edu.pl

Polskie muzułmanki. W poszukiwaniu tożsamości to praca podejmująca ważny temat konwersji polskich kobiet na islam. Książka Moniki Ryszewskiej napisana na podstawie badań empirycznych wypełnia ważną lukę w literaturze poświęconej konwersji na islam w polskim kontekście społeczno-kulturowym ${ }^{1}$. Jest to temat trudny ze względu na imponującą różnorodność motywów i niepowtarzalność historii każdej z konwertytek, co sprawia, że niełatwo jest sformułować „socjologicznie satysfakcjonujące" wyjaśnienia tego zjawiska². Dodatkową trudność niesie rozpowszechniona w społeczeństwie polskim emocjonalna dezaprobata muzułmanów i konwertytów na islam, wzmacniana przez część środowisk politycznych i media. Podejmując ten temat, autorka obiera sobie zatem za przedmiot badań problem „emocjonalnie obciążony", ujmowany na różne sposoby w potocznej percepcji i reprezentacji. Analiza problemu, którą podejmuje, posługując się socjologiczną teorią i metodą, pozwala spojrzeć na konwersję na islam w sposób bardziej neutralny i systematyczny. Zaletą tej pracy jest to, że autorka, opisując doświadczenia polskich konwertytek, swoje własne emocje bierze w nawias.

${ }^{1}$ Najważniejsze dotychczasowe prace prezentują jedynie wybrane, wąskie aspekty doświadczenia konwersji na islam w Polsce. Większość z tych opracowań to niepublikkowane prace magisterskie lub licencjackie lub materiały dziennikarskie (np. A.J. Dudek, Poddaję się. Życie muzułmanek w Polsce, Warszawa 2016).

${ }^{2}$ K. van Nieuwkerk, Gender, Conversion and Islam. A Comparison of off Line and on Line Conversion Narratives [w:] Women Embracing Islam: Gender and Conversion in the West, K. van Nieuwkerk (red.), Texas 2009, s. 95. 
W tytule Ryszewska z rozmachem zakreśla obszar swoich zainteresowań, który obejmuje „polskie muzułmanki” - grupę mało liczebną, ale bardzo zróżnicowaną. Termin ten zostaje uściślony: określenie „polskie muzułmanki” w tym wypadku odnosi się do konwertytek (Polek wychowanych w tradycji katolickiej lub na jej obrzeżach, które przyjęły islam) i Tatarek, nie obejmuje zaś imigrantek wyznających islam mieszkających w Polsce. Głównym punktem wyjścia dyskusji są doświadczenia konwertytek, ale zestawienie doświadczeń wychowanych $\mathrm{w}$ islamie Tatarek i kobiet, które przyjęły islam jako osoby dorosłe, znacznie rozszerza pole badawcze. Takie porównanie potencjalnie niesie za sobą ryzyko nieuprawnionego ujednolicania bardzo odmiennych doświadczeń, jednak dobrze przeprowadzona analiza doświadczeń wspólnych dla tych dwóch grup, a jednocześnie zachowanie ich jednostkowego charakteru dały nową perspektywę i pozwoliły na uwzględnienie takich aspektów badanego zjawiska, które mogłyby zostać pominięte, gdyby badania skupiały się tylko na jednej grupie osób. Autorka przedstawia swoje obserwacje w specyficznym polskim kontekście historycznym i społeczno-kulturowym i uwzględnia te czynniki kontekstowe w swoich analizach. Książka traktuje więc o doświadczeniach przyjęcia islamu i bycia muzułmanką w Polsce.

Monografia składa się z sześciu rozdziałów i zakończenia. W pierwszym rozdziale autorka wprowadza czytelnika w swoje badania empiryczne, opisując, co skłoniło ją do podjęcia problematyki tożsamości polskich muzułmanek, oraz krótko omawiając zebrane dane i kryteria doboru osób badanych. Autorka wiele czasu i energii poświęciła na to, żeby przygotować się do prowadzenia badań na temat związany z islamem i dobrać odpowiednio zróżnicowaną grupę osób badanych. Dane, które stanowią podstawę prezentowanych w książce rozważań, pochodzą z wywiadów z liderami społeczności muzułmańskich w Polsce, wywiadów ze starannie wybranymi do tego celu konwertytkami i Tatarkami oraz dane z obserwacji uczestniczącej. Chociaż bogactwo danych jest dużą zaletą tej pracy, decyzja autorki o przeprowadzeniu obserwacji ukrytej podczas jednego ze zjazdów muzułmańskich może budzić wątpliwości natury etycznej. Badaczka, przyjmując „fałszywą tożsamość”, jak sama to określa, wkroczyła w przestrzeń zarezerwowaną wyłącznie dla wyznawców islamu po to, by ich ,podglądać w ich naturalnym środowisku". Autorka jest jednak do pewnego stopnia świadoma problematycznej natury tak prowadzonej obserwacji i sama porusza temat przekraczania granic etycznych w badaniach.

Na rozdział drugi składa się obszerna dyskusja dotycząca teoretycznych ujęć tożsamości, definicji religii i religijności i sposobów konceptualizacji konwersji. Taka próba uporządkowania definicji i modeli teoretycznych w obszarze badań, w którym porusza się autorka, jest niemal obowiązkowym wstępem do części empirycznej, który zazwyczaj kończy się deklaracją swojego stanowiska. W tej części autorka sięga zarówno do opracowań Elżbiety Hałas na temat konwersji i Zbigniewa Bokszańskiego na temat tożsamości, jak i do źródeł oryginalnych. Po dokonaniu przeglądu wybranych modeli teoretycznych autorka nie decyduje się na ostateczne osadzenie własnej pracy w konkretnym modelu konwersji czy przyjęcie jednej definicji religii, ale ukierunkowuje swoje dociekania poprzez deklarację swoich teoretycznych preferencji. Praca Ryszewskiej wpisuje się w nurt badań nad konwersją, w których socjologiczne i psychologiczne modele konwersji służą za punkt odniesienia w interpretacji danych jakościowych 
pochodzących z wywiadów z konwertytami i pomagają badaczom porządkować zebrane dane przy użyciu właściwych sobie kategorii. Autorka deklaruje, że najbliższym jej modelem konwersji jest ujęcie Richarda Travisano, który definiuje konwersję jako reorganizację tożsamości. Badaczka przyjmuje perspektywę interakcjonistyczną i tożsamość traktuje jako proces. Za Sheldonem Strykerem zakłada, że tożsamość ma strukturę hierarchiczną, a poszczególne aspekty tożsamości uwydatniają się mniej lub bardziej w zależności od kontekstu.

W trzecim rozdziale został zarysowany lokalny kontekst podjętych przez autorkę badań i krótko zaprezentowane tło historyczne i współczesne strukturalne warunki funkcjonowania islamu w Polsce. Ta część pracy stanowi bardzo przystępne skrótowe wprowadzenie do problematyki ,polskiego islamu” dla osób, które stykają się z tym tematem po raz pierwszy. Niewątpliwą zaletą tej części jest również aktualizacja stanu wiedzy na ten temat. Autorka nie tylko sięga do wcześniej publikowanych opracowań dotyczących islamu w Polsce, ale uzupełnia dotychczas dostępne dane faktograficzne (np. szacunki dotyczące liczby konwertytów czy członków poszczególnych organizacji muzułmańskich działających w Polsce) o dane zdobyte podczas własnej pracy empirycznej (wywiady z liderami organizacji zrzeszających muzułmanów, dane pochodzące z mediów społecznościowych). Tutaj należy jednak zastrzec, że nie zostały zebrane w systematyczny sposób, mają charakter szacunkowy i mogą być obciążone błędem.

W kolejnych dwóch rozdziałach autorka pisze o doświadczeniach polskich konwertytek. Mimo że badaczka świadomie rezygnuje z analizy biograficznej, w przekonujący sposób pokazuje, jak islam wpasowuje się w biografie konwertytek. Poprzez obszerne „opisy przypadków” odsłania procesy tożsamościowe, które pozwalają zrozumieć, dlaczego dla każdej z tych kobiet islam jest ,najlepszą” religią. Autorka czyni to ze świadomością, że owo wpasowanie jest wynikiem rekonstrukcji biograficznej aktywnie podejmowanej przez osoby badane, choć w niektórych fragmentach zdaje się stawiać niepotrzebne pytanie o zgodność relacji osób badanych z faktami. Materiał empiryczny prezentowany w tej części autorka usiłuje uporządkować według podziału doświadczeń osób badanych na te ,przed konwersją” i ,po konwersji”. Pomimo tego, że kilkakrotnie podkreśla zalety przyjęcia takiego podziału, nie udaje się jej do końca utrzymać go w prezentacji zebranego materiału (np. w rozdziale ,przed konwersją” pojawiają się bardzo obszerne fragmenty dotyczące tego, jak konwertytki funkcjonują w związkach po konwersji). Ta trudność akcentuje procesualny charakter konwersji, rozmyte granice biograficznych pęknięć i podziałów oraz ciągłość jako jedną z podstawowych kategorii tożsamości. Uświadamia czytelnikowi, że nie jest jasne, w którym momencie tego procesu należałoby przestać mówić o „przed”, a zacząć posługiwać się kategorią „po”. Ta część pracy obfituje w narracje badanych osób przytaczane w obszernych fragmentach. Narracje te są uporządkowane tematycznie w taki sposób, że tworzą opowieść, która wciąga czytelnika w świat polskich muzułmanek, zabiera go w podróż po ich zróżnicowanych doświadczeniach, wyborach i motywach. Podstawową trudnością w procesie dzielenia tych opowieści na małe fragmenty i scalania ich w nową całość, podkreślającą to, co wspólne w doświadczeniach osób badanych, jest unikanie zbytnich uproszczeń i oddanie złożoności tych doświadczeń. Badaczka nie wyczerpuje jednak możliwości, jakie daje podjęty sposób analizy. Komentarze, jakimi opatrzone są wypowiedzi osób 
badanych, w większości przypadków są parafrazą tych wypowiedzi, a polemiki autorki z innymi badaczami konwersji cechują się dużą ostrożnością i wydają się niedokończone. Pomimo tej ostrożności niektóre szczegółowe i ogólne wnioski mogą budzić kontrowersje. Część czytelników nie zgodzi się zapewne z tezą, że dla części kobiet konwersja jest sposobem wyróżnienia się z tłumu. Choć ton całej pracy jest neutralny i autorka unika stawiania sądów normatywnych, taka interpretacja implikuje pewnego rodzaju niedojrzałość osób badanych i ma wydźwięk pejoratywny.

Autorka deklaruje, że przyjmuje perspektywę interakcjonistyczną, ale w swoich analizach bardzo niewiele uwagi poświęca interakcyjnemu charakterowi danych pochodzących z wywiadów. Brakuje więc refleksji na temat tego, jaką rolę w konstruowaniu opowieści odgrywa kontekst wypowiedzi; jaki wpływ na to, co mówią i jak mówią rozmówczynie, ma osoba badaczki. W dyskusji Ryszewska pomija problem negocjowania ról badacza i osoby badanej w sytuacji wywiadu. Autorka niewiele uwagi poświęca temu, kto jest domniemanym odbiorcą wypowiedzi osób badanych i jak sposób rozumienia sytuacji badawczej kształtuje wypowiedzi osób badanych.

W szóstym rozdziale autorka skupia się na polskich Tatarkach. Rozważania prezentowane w tej części książki kierują uwagę czytelnika na złożone związki między religią a identyfikacją etniczną. Badaczka nakreśla specyfikę islamu tatarskiego i istniejące napięcia między ,islamem rodzimym” a „islamem arabskim”. Poprzez zaprezentowanie kilku studiów przypadków pokazuje różnorodność relacji polskich Taterek z islamem i tatarskością, nieoczywistość związku między islamem a tożsamością etniczną w doświadczeniach rozmówczyń oraz ich aktywną, kreatywną postawę w tworzeniu własnej tożsamości.

Książka Ryszewskiej dostarcza bogatego materiału opisowego. Badaczka pokazuje złożoność procesu konwersji i różnorodność dróg, jakie prowadzą kobiety do przyjęcia islamu. Autorka odsłania tożsamość osób badanych w ich codziennych praktykach, takich jak modlitwa, post, w relacjach z innymi jednostkami i grupami. Pokazuje, jak kształtowana jest ich tożsamość i jak się przejawia w komunikacji werbalnej i niewerbalnej. W swoich opisach badaczka zapoznaje czytelnika ze zmianami zachodzącymi w życiu konwertytek w procesie konwersji. Zmiany te obejmują praktyki społeczne i kulturowe i niosą doniosłe konsekwencje w relacjach ze znaczącymi osobami (członkami rodziny, przyjaciółmi, przełożonymi). Badaczka uwzględnia polski kontekst i formułuje wniosek, że w niektórych przypadkach konwersja jest wyrazem buntu przeciwko dominującym, esencjalistycznym kategoriom narodowo-etnicznym, które postulują ścisły związek między religią i narodowością. W ujęciu autorki konwersja na islam to proces, który dotyczy nie tylko jednostek, ale również grup zdefiniowanych na podstawie różnorodnych kryteriów: kobiet, rodzin, wspólnot etnicznych, religijnych i narodowych (Tatarek, Arabów, Polek, katolików). Tym samym praca Ryszewskiej stanowi wkład w debatę na temat islamu europejskiego. Jest to ważna próba ,przezwyciężenia władzy bezimiennego «wiadomo, że...»"3 i przekształcenia wielu powszechnych przekonań w pytania. Poprzez analizę zebranych danych autorka próbuje przede wszystkim zmierzyć się ze stereotypami dotyczącymi motywów konwersji (,zauroczenie Arabem”) czy pozycji kobiet w islamie. W swoich rozważaniach jednak bardzo mało uwagi

3 J. Szacki. Tradycja, Warszawa 2011, s. 36. 
poświęca mechanizmom legitymizującym przekonania, które próbuje podważać - populistycznym strategiom wytwarzania „religijnego innego" i „moralnej paniki” czy też relacjom dominacji i władzy, w jakich funkcjonują polskie muzułmanki. Pomimo tego, że taka perspektywa nie pojawia się w prezentowanych analizach, rzetelny opis związków badanych kobiet z niektórymi grupami czy organizacjami skłania czytelnika do refleksji nad procesem konstruowania i legitymizowania hierarchii społecznych. Książka odsłania kilka istotnych aspektów tego pola badań. Jak można się spodziewać, praca ta nie prowadzi do żadnych „twardych” czy ostatecznych wniosków, ale pokazuje złożoną, wielowymiarową naturę zjawiska konwersji. Konkluzje zaproponowane przez autorkę w niektórych momentach mogą budzić sprzeciw, ale prowokują do stawiania nowych pytań i uświadamiają, jak wiele ciągle czeka na odpowiedzi. 